\title{
Structure and magnetic properties of Co-Zn substituted hexagonal ferrites
}

\author{
Erfan Handoko ${ }^{1, *}$, Anggoro B S ${ }^{1}$, Iwan Sugihartono ${ }^{1}$, Mangasi $\mathrm{AM}^{1}$, Dini Siti Nurwulan ${ }^{1}$, Serafin Christina $^{1}$, and \\ Zulkarnain Jalil ${ }^{2}$
}

${ }^{1}$ Universitas Negeri Jakarta, Dept of Physics, Jalan Rawamangun Muka 13220, Jakarta, Indonesia

${ }^{2}$ Syiah Kuala University, Dept. of Physics, Banda Aceh, Indonesia

\begin{abstract}
In In this study to understand the substitutional effect of Co-Zn on structural and magnetic properties of the $\mathrm{BaFe}_{12-2 \mathrm{x}} \mathrm{Cox}_{\mathrm{x}} \mathrm{Zn}_{\mathrm{x}} \mathrm{O}_{19} \mathrm{M}$-type hexagonal ferrites with concentration $(\mathrm{x}=0.0,0.2,0.4,0.6,0.8$, 1.0) were synthesized by the ceramic method. The results of $x$-ray diffraction show polycrystalline with single phase. Scanning electron microscopy micrographs shows the hexagonal ferrites that are composed of small particles with large porosity, roughly of spherical shapes. The substitution of $\mathrm{Fe}^{3+}$ ion by $\mathrm{Co}^{2+}$ and $\mathrm{Zn}^{2+}$ has changed magnetic properties of hexagonal ferrites.
\end{abstract}

\section{Introduction}

The hexagonal ferrites as permanent magnets have been used for thousands of years [1] and play an important role in daily-life applications [2-6]. The development of magnetic materials with material derived from mineral minerals has been first described in 1925 and continues in 1938 the hexagonal crystal with the composition $\mathrm{PbFe}_{7.5} \mathrm{Mn}_{3.5} \mathrm{Al}_{0.5} \mathrm{Ti}_{0.5} \mathrm{O}_{19}$ [7]. A few years ago Philips Laboratories had developed ferrites $\left(\mathrm{BaFe}_{12} \mathrm{O}_{19}\right)$ that is known by many names, including barium hexaferrite, barium ferrite, hexagonal ferrite, ferroxdure, Mferrite and $\mathrm{BaM}$ had a high electrical resistivity of $108 \Omega \mathrm{cm}$ and the high magnetic uniaxial anisotropy along the c-axis. The compound hexagonal ferrite, $\mathrm{BaFe}_{12} \mathrm{O}_{19}$ with a melting point of $1390 \mathrm{oC}$, a coercivity of $160-255 \mathrm{kA} / \mathrm{m}$, magnetically hard, the maximum density is $5.295 \mathrm{~g} / \mathrm{cm} 3$ [8-12]. The effect of dopants on hexagonal ferrite has been largely done by researchers in order to enhance the properties of the magnet. Amitava Moitra et.al investigated aluminum-substituted M-type barium hexaferrite [13]. M-type hexagonal ferrites with $\mathrm{BaCo}_{\mathrm{x}} \mathrm{Fe}_{12-\mathrm{x}} \mathrm{O}_{19}(\mathrm{x}=2.0,3.0)$ composition had prepared by C. C. Chauhan at.al [14]. $\mathrm{Al}^{3+}$ and $\mathrm{Cr}^{3+}$ co-substituted barium hexaferrite $\mathrm{BaCr}_{\mathrm{x}} \mathrm{Al}_{\mathrm{x}} \mathrm{Fe}_{12-2 \mathrm{x}} \mathrm{O} 19(\mathrm{x}=0.0,0.2,0.4$, 0.6, 0.8 and 1.0) nanoparticles had showed all the magnetic parameters saturation magnetization $\left(\mathrm{M}_{\mathrm{s}}\right)$, remanence magnetization $\left(\mathrm{M}_{\mathrm{r}}\right)$ and coercivity $\left(\mathrm{H}_{\mathrm{c}}\right)$ decreases with increase of $\mathrm{Al}^{3+}$ and $\mathrm{Cr}^{3+}$ content $\mathrm{x}$ [15]. The substitution of $\mathrm{Co}^{2+}$ and $\mathrm{Ti}^{4+}$ ions in barium ferrite mainly lead to the replacement $\mathrm{Fe}^{3+}$ ions distributed in octahedral positions $12 \mathrm{k}$ and $4 \mathrm{f}_{2}$ and had decreased of the coercivityfor $\mathrm{x}=0$ is clearlyobserved for the value 391 $\mathrm{kA} / \mathrm{m}$ and drops down to $35 \mathrm{kA} / \mathrm{m}$ for $\mathrm{x}=1.2$ [16]. $\mathrm{BaFe}_{10} \mathrm{Al}_{2} \mathrm{O}_{19} /$ poly (o-toluidine) (BFA/POT) composite [17], $\mathrm{Co}_{2} \mathrm{Z}$ barium ferrite composite with the added graphite powder [18], $\mathrm{Fe}^{3 \square}$ ion in barium hexaferrite were replaced by magnetic $(\mathrm{Mn}, \mathrm{Co}, \mathrm{Ni}$ and $\mathrm{Cu})$, non-magnetic (Zn) and dielectric ions (Ti) [19] were prepared for microwave absorbing properties. This paper is to report a detailed microstructural and magnetic study of the $\mathrm{BaFe}_{12}$ ${ }_{2 x} \mathrm{Co}_{\mathrm{x}} \mathrm{Zn}_{\mathrm{x}} \mathrm{O}_{19} \quad$ M-type hexagonal ferrites with concentration $\mathrm{x}=0.0,0.2,0.4,0.6,0.8,1.0$ using $\mathrm{x}$-ray diffraction (XRD) and scanning electron microscope (SEM) for analyzing its structures, and permagraph techniques for magnetic properties.

\section{Experimental procedure}

Hexagonal ferrite, $\mathrm{BaFe}_{12-2 \mathrm{x}} \mathrm{Co}_{\mathrm{x}} \mathrm{Zn}_{\mathrm{x}} \mathrm{O}_{19}$ M-type hexagonal ferrites $(x=0.0,0.2,0.4,0.6,0.8,1.0)$ were synthesized from stoichiometric mixtures of $\mathrm{Fe}_{2} \mathrm{O}_{3}, \mathrm{BaCO}_{3}, \mathrm{Co}_{3} \mathrm{O}_{4}$, $\mathrm{ZnO}$ and by the ceramic method. Samples were sintered at $1100{ }^{\circ} \mathrm{C}$ for $3 \mathrm{~h}$. The samples were characterized using Phillips x-ray diffraction (XRD) Co-K $\alpha$ with $40 \mathrm{kV}$ and $30 \mathrm{~mA}$ and scanning electron microscopy FE-SEM FEI Inspect F50 for analyzing structures, hysteresis loops recorded by Permagraph techniques from magnet physik Dr. Steingroever $\mathrm{GmbH}$ with maximum external field of 1 tesla for magnetic properties.

\section{Results and discussion}

The hexagonal ferrites were characterized using x-ray diffraction (XRD) Phillips Co-Ka with $2 \square$ interval $30-$ $60^{\circ}$ for analyzing the structure. Figure 1 shows XRD patterns of the $\mathrm{BaFe}_{12-2 \mathrm{x}} \mathrm{Co}_{\mathrm{x}} \mathrm{Zn}_{\mathrm{x}} \mathrm{O}_{19}$ powder, with various compositions of $\mathrm{x}(\mathrm{x}=0.0,0.2,0.4,0.6,0.8,1.0)$. According to the reference pattern of international crystal diffraction data (ICDD) number \#98-015-7056, the

\footnotetext{
* Corresponding author: erfan@unj.ac.id
} 
crystal structure of samples $\mathrm{BaFe}_{12-2 \mathrm{x}} \mathrm{Co}_{\mathrm{x}} \mathrm{Zn}_{\mathrm{x}} \mathrm{O}_{19}$ are polycrystalline with single phase.

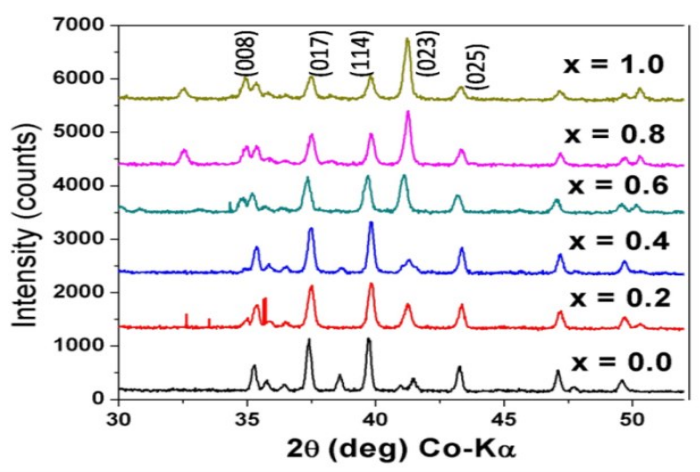

Fig.1. XRD pattern of $\mathrm{BaFe}_{12-2 \mathrm{x}} \mathrm{Co}_{\mathrm{x}} \mathrm{Zn}_{\mathrm{x}} \mathrm{O}_{19}$ hexagonal ferrites $(x=0.0,0.2,0.4,0.6,0.8,1.0)$.

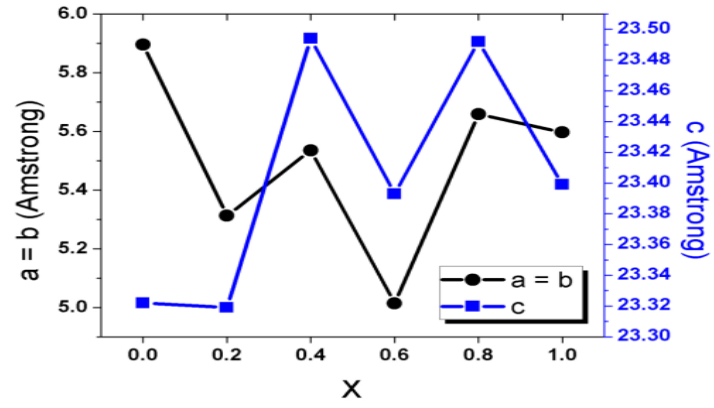

Fig. 2. The lattice parameter of $\mathrm{BaFe}_{12-2 \mathrm{x}} \mathrm{Co}_{\mathrm{x}} \mathrm{Zn}_{\mathrm{x}} \mathrm{O}_{19}$ hexagonal ferrites $(\mathrm{x}=0.0 ; 0.2 ; 0.4 ; 0.6 ; 0.8 ; 1.0)$.

This indicates that $\mathrm{Co}$ and $\mathrm{Zn}$ ions have been successfully substituted the Fe ions. As seen from the Fig. 1 , we observed ten crystal orientations such as (008), (017), (114), (023), (025). In the crystal orientations (017) and (114), clearly observed that the peaks of $\mathrm{BaFe}_{12}$ ${ }_{2 \mathrm{x}} \mathrm{Co}_{\mathrm{x}} \mathrm{Zn}_{\mathrm{x}} \mathrm{O}_{19}$ decrease by $\mathrm{Co}-\mathrm{Zn}$ incorporation. This should be attributed to the change of lattice parameter values from the standard of $\mathrm{BaFe}_{12-2 \mathrm{x}} \mathrm{Co}_{\mathrm{x}} \mathrm{Zn}_{\mathrm{x}} \mathrm{O}_{19}$ which refer to ICDD no. 98-015-7056. The changes in the lattice parameter can be caused $\mathrm{Co}-\mathrm{Zn}$ substituted ions. Lattice parameter of all samples are shown in table 1.

Table 1. The lattice parameter and average crystallite size of $\mathrm{BaFe}_{12-2 \mathrm{x}} \mathrm{Cox}_{\mathrm{x}} \mathrm{Zn}_{\mathrm{x}} \mathrm{O}_{19}$ hexagonal ferrites $(\mathrm{x}=0.0 ; 0.2 ; 0.4 ; 0.6$; $0.8 ; 1.0)$.

\begin{tabular}{|c|c|c|c|}
\hline \multirow{2}{*}{$\begin{array}{c}\text { Composition } \\
\mathrm{BaFe}_{12-2 \mathrm{x}} \mathrm{Co}_{\mathrm{x}} \mathrm{Zn}_{\mathrm{x}} \mathrm{O}_{19}\end{array}$} & \multicolumn{3}{|c|}{ Lattice parameter } \\
\cline { 2 - 4 } & $\mathrm{A}(\AA)$ & $\mathrm{b}(\AA)$ & $\mathrm{c}(\AA)$ \\
\hline $\mathrm{BaFe}_{12} \mathrm{O}_{19}$ & 5.896 & 5.896 & 23.322 \\
\hline $\mathrm{BaFe}_{11.6} \mathrm{Co}_{0.2} \mathrm{Zn}_{0.2} \mathrm{O}_{19}$ & 5.313 & 5.313 & 23.319 \\
\hline $\mathrm{BaFe}_{11.2} \mathrm{Co}_{0.4} \mathrm{Zn}_{0.4} \mathrm{O}_{19}$ & 5.535 & 5.535 & 23.494 \\
\hline $\mathrm{BaFe}_{10.8} \mathrm{Co}_{0.6} \mathrm{Zn}_{0.6} \mathrm{O}_{19}$ & 5.014 & 5.014 & 23.393 \\
\hline $\mathrm{BaFe}_{10.4} \mathrm{Co}_{0.8} \mathrm{Zn}_{0.8} \mathrm{O}_{19}$ & 5.659 & 5.659 & 23.492 \\
\hline $\mathrm{BaFe}_{10} \mathrm{CoZnO}_{19}$ & 5.597 & 5.597 & 23.399 \\
\hline
\end{tabular}
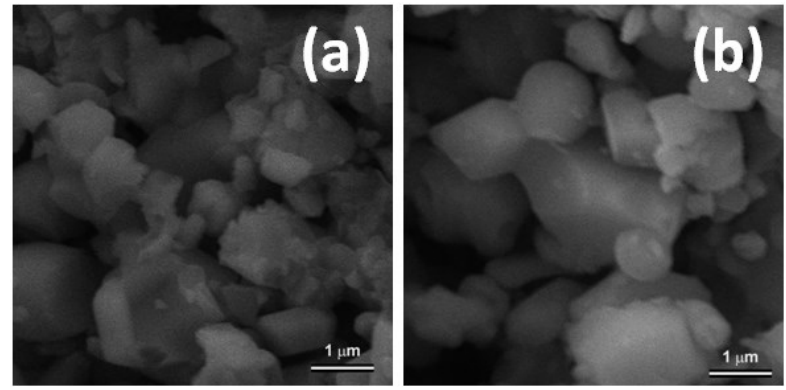

Fig. 3. The SEM micrographs of $\mathrm{BaFe}_{12-2 \mathrm{x}} \mathrm{Co}_{\mathrm{X}} \mathrm{Zn}_{\mathrm{x}} \mathrm{O}_{19}$ hexagonal ferrites (a) $x=0.2$ and (b) $x=0.4$

Figure 3 shows the SEM micrographs of the hexagonal ferrites $\mathrm{BaFe}_{12-2 \mathrm{x}} \mathrm{Co}_{\mathrm{x}} \mathrm{Zn}_{\mathrm{x}} \mathrm{O}_{19}(\mathrm{x}=0.0 ; 0.2 ; 0.4$; $0.6)$ powders. The barium hexaferrite are composed of small particles with large porosity, roughly of spherical shapes, less than $2 \mu \mathrm{m}$ after milling for 1 hour by using high energy ball mill. While the lattice parameters changes (table 1), according to the SEM micrographs (Fig.3) show no particle size change significantly that caused by substitution of $\mathrm{Fe}^{3+}$ ion by $\mathrm{Co}^{2+}$ and $\mathrm{Zn}^{2+}$.

Figure 4 shows hysteresis loops in the second quadrant and the magnetic energy density $(\mathrm{BH})_{\max }$ of hexagonal ferrites that obtained from measurement using Permagraph techniques from magnet physik Dr. Steingroever $\mathrm{GmbH}$ with maximum external field of 1 tesla. The substitution of $\mathrm{Fe}^{3+}$ ion by $\mathrm{Co}^{2+}$ and $\mathrm{Zn}^{2+}$ has changed magnetic properties of hexagonal ferrites such as remanent magnetization $\left(M_{r}\right)$, coercive force $\left(H_{c}\right)$, the saturation magnetization $\left(\mathrm{M}_{\mathrm{s}}\right)$ and magnetic energy density $(\mathrm{BH})_{\max }$. From tables two can observe $\mathrm{M}_{\mathrm{s}}, \mathrm{M}_{\mathrm{r}}, \mathrm{H}_{\mathrm{c}}$ and $(\mathrm{BH})_{\max }$ values vary from 0.23 to $0.32 \mathrm{~T}, 0.153$ to $0.184 \mathrm{~T}, 40.67$ to $229.89 \mathrm{kA} / \mathrm{m}$ and 1.36 to $16.47 \mathrm{~kJ} / \mathrm{m}^{3}$, respectively. Ms value increases unsignificantly, while $\mathrm{Hc}$ and $(\mathrm{BH})_{\max }$ values decreases with increasing substitution of $\mathrm{Co}$ and $\mathrm{Zn}$ in $\mathrm{Fe}$. On the other hand, $\mathrm{Mr}$ value increases with $\mathrm{x}=0$ to $\mathrm{x}=0.4$ and decreases with $x=0.6$ to $x=1.0$. This is because the limit of the substitution of $\mathrm{Fe}^{3+}$ ion by $\mathrm{Co}^{2+}$ and $\mathrm{Zn}^{2+}$ of hexagonal ferrites.

Table 2. Magnetic values of $\mathrm{BaFe}_{12-2 \mathrm{x}} \mathrm{Co}_{\mathrm{x}} \mathrm{Zn}_{\mathrm{x}} \mathrm{O}_{19}$ hexagonal ferrites $(\mathrm{x}=0.0 ; 0.2 ; 0.4 ; 0.6 ; 0.8 ; 1.0)$.

\begin{tabular}{|c|c|c|c|c|}
\hline $\begin{array}{c}\text { Composition } \\
\mathrm{BaFe}_{12-2 \mathrm{x}} \mathrm{Co}_{\mathrm{x}} \mathrm{Zn}_{\mathrm{x}} \mathrm{O}_{19}\end{array}$ & $\begin{array}{c}\mathrm{M}_{\mathrm{r}} \\
(\mathrm{T})\end{array}$ & $\begin{array}{c}\mathrm{H}_{\mathrm{c}} \\
(\mathrm{kA} / \mathrm{m})\end{array}$ & $\begin{array}{c}\mathrm{M}_{\mathrm{s}} \\
(\mathrm{T})\end{array}$ & $\begin{array}{c}\mathrm{BH}_{\text {maks }} \\
\left(\mathrm{kJ} / \mathrm{m}^{3}\right)\end{array}$ \\
\hline $\mathrm{BaFe}_{12} \mathrm{O}_{19}$ & 0.153 & 229.89 & 0.23 & 16.47 \\
\hline $\mathrm{BaFe}_{11.6} \mathrm{Co}_{0.2} \mathrm{Zn}_{0.2} \mathrm{O}_{19}$ & 0.182 & 108.38 & 0.28 & 5.00 \\
\hline $\mathrm{BaFe}_{11.2} \mathrm{Co}_{0.4} \mathrm{Zn}_{0.4} \mathrm{O}_{19}$ & 0.184 & 129.97 & 0.27 & 7.04 \\
\hline $\mathrm{BaFe}_{10.8} \mathrm{Co}_{0.6} \mathrm{Zn}_{0.6} \mathrm{O}_{19}$ & 0.170 & 58.96 & 0.29 & 3.08 \\
\hline $\mathrm{BaFe}_{10.4} \mathrm{Co}_{0.8} \mathrm{Zn}_{0.8} \mathrm{O}_{19}$ & 0.169 & 66.20 & 0.30 & 2.39 \\
\hline $\mathrm{BaFe}_{10} \mathrm{CoZnO}_{19}$ & 0.155 & 40.67 & 0.32 & 1.36 \\
\hline
\end{tabular}



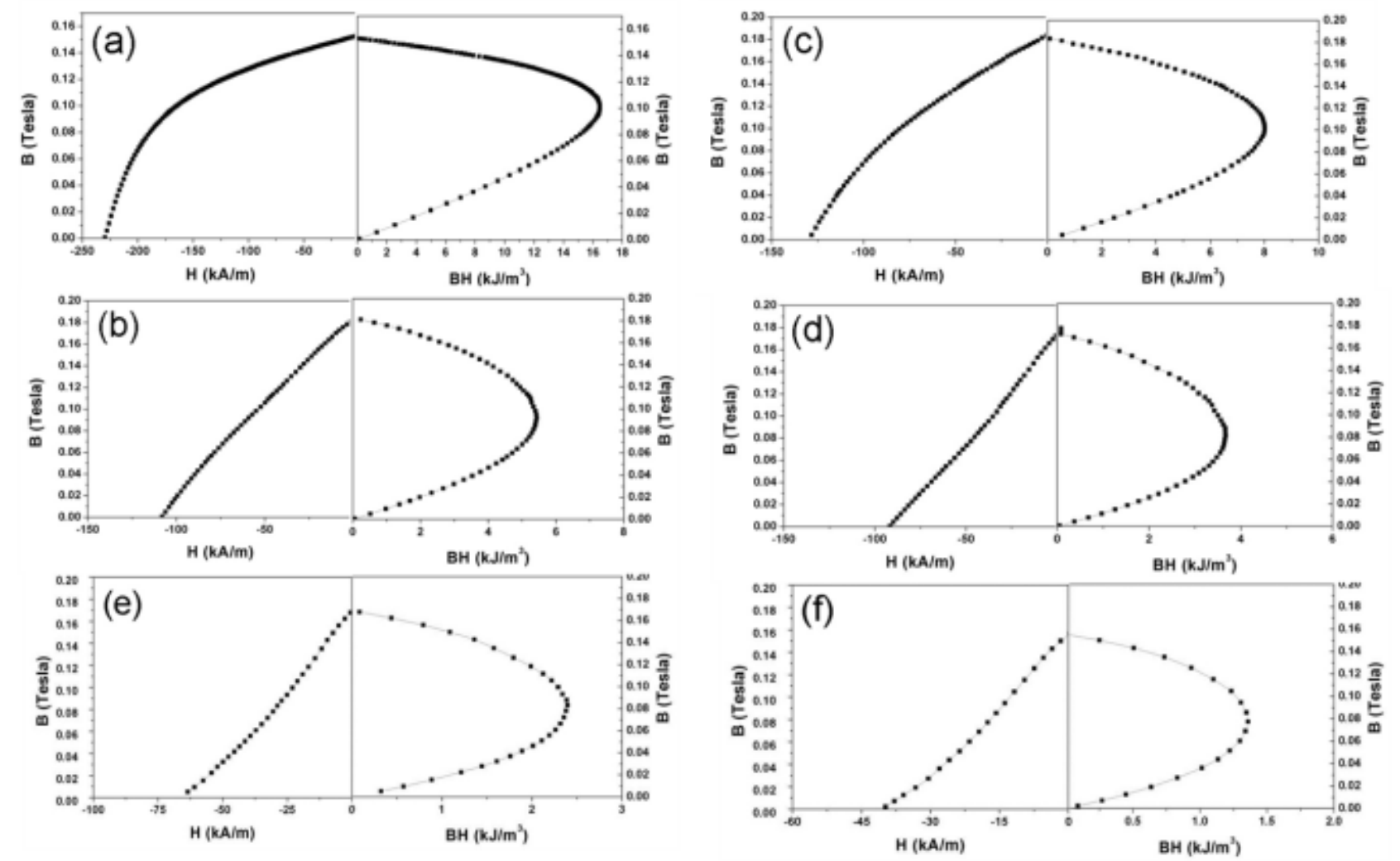

Fig. 4. Room temperature hysteresis loops of $\mathrm{BaFe}_{12-2 \mathrm{x}} \mathrm{Co}_{\mathrm{x}} \mathrm{Zn}_{\mathrm{x}} \mathrm{O}_{19}$ hexagonal ferrites $(\mathrm{x}=0.0 ; 0.2 ; 0.4 ; 0.6 ; 0.8 ; 1.0)$

\section{Conclusions}

Hexagonal ferrites $\mathrm{BaFe}_{12-2 \mathrm{x}} \mathrm{Co}_{\mathrm{x}} \mathrm{Zn}_{\mathrm{x}} \mathrm{O}_{19}$ with $\mathrm{x}=0.0 ; 0.2$; $0.4 ; 0.6 ; 0.8 ; 1.0$ were prepared the ceramic method successfully. According to the diffraction pattern of all samples are polycrystalline with single phase. SEM micrographs shows the hexagonal ferrites that are composed of small particles with large porosity, roughly of spherical shapes and less than $2 \mu \mathrm{m}$. The substitution of $\mathrm{Fe}^{3+}$ ion by $\mathrm{Co}^{2+}$ and $\mathrm{Zn}^{2+}$ has changed magnetic properties of hexagonal ferrites. $M_{s}$ value increases, while $\mathrm{H}_{\mathrm{c}}$ and $(\mathrm{BH})_{\max }$ values decreases. On the other hand, $\mathrm{M}_{\mathrm{r}}$ value increases with $\mathrm{x}=0$ to $\mathrm{x}=0.4$ and decreases with $\mathrm{x}=0.6$ to $\mathrm{x}=1.0$.

The authors thank Kementerian Riset, Teknologi dan Pendidikan Tinggi Republik Indonesia under grant PUPT 2018 for the financial support

\section{References}

1. K.-H. Müller, G. Krabbes, J. Fink, S. Gruß, A. Kirchner, G. Fuchs, and L. Schultz, "New permanent magnets," J. Magn. Magn. Mater., vol. 226-230, pp. 1370-1376, (2001).

2. S. W. Eun, W. H. Choi, H. K. Jang, J. H. Shin, J. B. Kim, and C. G. Kim, "Effect of delamination on the electromagnetic wave absorbing performance of radar absorbing structures," Compos. Sci. Technol., vol. 116, pp. 18-25, (2015).

3. R. H. Kadam, S. T. Alone, G. K. Bichile, and K. M. Jadhav, "Measurement of atomic number and mass attenuation coefficient in magnesium ferrite," Pramana - J. Phys., vol. 68, no. 5, pp. 869-874, (2007).

4. Erfan Handoko, et al, "Measurement of Complex Permittivity and Permeability ofHexagonal Ferrite Composite Material Using a Waveguide in Microwave Band," 2016 International Conference on Radar, Antenna, Microwave, Electronics, and Telecommunications Measurement pp. 28-30, (2016).

https://doi.org/10.1109/ICRAMET.2016.7849576

5. Erfan Handoko et al (2018) Mater. Res. Express in press https://doi.org/10.1088/2053-1591/aac4d7.

6. K. Khan and S. Rehman, "Microwave absorbance properties of zirconium-manganese substituted cobalt nanoferrite as electromagnetic (EM) wave absorbers," Mater. Res. Bull., vol. 50, pp. 454-461, (2014).

7. R. C. Pullar, "Hexagonal ferrites: A review of the synthesis, properties and applications of hexaferrite ceramics," Prog. Mater. Sci., vol. 57, no. 7, pp. 11911334, (2012).

8. P. E. Garcia-Casillas, A. M. Beesley, D. Bueno, J. A. Matutes-Aquino, and C. A. Martinez, "Remanence properties of barium hexaferrite," J. Alloys Compd., vol. 369, no. 1-2, pp. 185-189, (2004).

9. G. Tan and X. Chen, "Structure and multiferroic properties of barium hexaferrite ceramics," J. Magn. Magn. Mater., vol. 327, pp. 87-90, (2013).

10. M. J. Molaei, A. Ataie, S. Raygan, M. R. Rahimipour, S. J. Picken, F. D. Tichelaar, E. Legarra, and F. 
Plazaola, "Magnetic property enhancement and characterization of nano-structured barium ferrite by mechano-thermal treatment," Mater. Charact., vol. 63, pp. 83-89, (2012).

11. U. Topal, H. Ozkan, and H. Sozeri, "Synthesis and characterization of nanocrystalline BaFe 12 O 19 obtained at $850 \mathrm{C}$ by using ammonium nitrate melt," J. Magn. Magn. Mater., vol. 284, pp. 416-422, (2004).

12. X. Shi, Y. Pu, and D. Liu, "Preparation of magnetic barium ferrite powders by microwave hydrothermal method," J. Ceram. Process. Res., vol. 13, no. SPL. ISS.2, pp. 414-417, (2012).

13. A. Moitra, S. Kim, S. G. Kim, S. C. Erwin, Y. K. Hong, and J. Park, "Defect formation energy and magnetic properties of aluminum-substituted M-type barium hexaferrite," Comput. Condens. Matter, vol. 1, no. 1, pp. 45-50, (2014).

14. C. C. Chauhan, R. B. Jotania, and K. R. Jotania, "Structural Properties of Cobalt Substituted Barium Hexaferrite Nanoparticles Prepared By a Thermal Treatment Method," vol. 4, no. 3, pp. 363-369, (2013).

15. R. C. Alange, P. P. Khirade, S. D. Birajdar, A. V. Humbe, and K. M. Jadhav, "Structural, magnetic and dielectrical properties of Al-Cr Co-substituted Mtype barium hexaferrite nanoparticles," J. Mol. Struct., vol. 1106, pp. 460-467, (2016).

16. J. Zhou, H. Ma, M. Zhong, G. Xu, Z. Yue, and Z. He, "Influence of Co-Zr substitution on coercivity in Ba ferrites," J. Magn. Magn. Mater., vol. 305, no. 2, pp. 467-469, (2006).

17. K. Chen, L. Li, G. Tong, R. Qiao, B. Hao, and X. Liang, "Fabrication and absorbing property of microwave absorbers based on BaAl2Fe10O19 and poly(o-toluidine)," Synth. Met., vol. 161, no. 21-22, pp. 2192-2198, (2011).

18. T. Wang, C. Pan, Y. Wang, G. Tan, H. Wang, R. Li, and $\mathrm{F}$. Li, "Improvement of absorption performance for $\mathrm{Co} 2 \mathrm{Z}$ barium ferrite composite by increasing the reflected electromagnetic wave from air-absorber interface," J. Magn. Magn. Mater., vol. 354, pp. 1216, (2014).

19. H. Sözeri, Z. Mehmedi, H. Kavas, and A. Baykal, "Magnetic and microwave properties of BaFe12O19 substituted with magnetic, non-magnetic and dielectric ions," Ceram. Int., vol. 41, no. 8, pp.96029609, (2015). 